\title{
Effect of storage on biochemical parameters of packed red blood cells of goats in citrate phosphate dextrose adenine/ saline adenine glucose mannitol*
}

\author{
(iD) \\ S. R. Anaz ${ }^{1 *}$, N. Madhavan Unny ${ }^{2}$, Usha N. Pillai ${ }^{3}$, Arun George ${ }^{4}$ and \\ R. Thirupathy Venkatachalapathy ${ }^{5}$ \\ Department of Veterinary Clinical Medicine, Ethics and Jurisprudence \\ College of Veterinary and Animal Sciences, Mannuthy, Thrissur-680651, \\ Kerala Veterinary and Animal Sciences University, Kerala, India
}

Citation: Anaz, S.R., Unny, M.N., Usha.N.P., George, A. and Venkatachalapathy, T.R. 2021. Effect of storage on biochemical parameters of packed red blood cells of goats in citrate phosphate dextrose adenine/ saline adenine glucose mannitol. J. Vet. Anim. Sci. 52(3): 257-261. DOI: https://doi.org/10.51966/jvas.2021.52.3.257-261

\begin{abstract}
A study was conducted to assess the suitability of citrate phosphate dextrose adenine / saline adenine glucose mannitol as a storage media for packed RBCs of goats. Samples collected from ten apparently healthy goats were utilized for the study. Biochemical studies were carried out on day 0, 14, 28 and 42 days of storage using the parameters, viz. $\mathrm{pH}$, glucose, potassium, malondialdehyde and reduced glutathione. The $\mathrm{pH}$ was stable throughout the study, whereas glucose showed significant reduction. Rest of the parameters increased significantly from $0^{\text {th }}$ day to $42^{\text {nd }}$ day. Based on the results, the storage media can be considered to be suitable for storing caprine packed RBCs.
\end{abstract}

Keywords: Biochemical parameters, blood transfusion, goat, packed RBCs, storage studies

With advances in veterinary transfusion medicine, blood component therapy is being increasingly practiced. Packed red blood cell (pRBC) transfusion is one of the most common component transfusion practiced in animal transfusions. As the need outweighs availability, storage of blood and its components is required for emergency transfusion procedures. Suitable storage media is a necessity with regard to storing of blood, as any storage lesion can adversely affect the viability of RBCs. Biochemical studies on caprine pRBCs stored in citrate phosphate dextrose adenine/ saline adenine glucose mannitol (CPDA/SAGM) are scarce. Hence, the present study was envisaged to assess the suitability of CPDA/SAGM as a storage media for caprine pRBCs.

${ }^{*}$ Part of M.V.Sc. thesis submitted by the first author to Kerala Veterinary and Animal Sciences University, Pookode, Wayanad, Kerala

1. MVSc Scholar and ${ }^{* *}$ corresponding author:email:anazsr2012@gmail.com,Ph:9846923713

2. Associate Professor

3. Professor and Head

4. Assistant Professor

5. Professor, Department of Animal Genetics and Breeding

Copyright: () 2021 Anaz et al. This is an open access article distributed under the terms of the Creative Commons Attribution 4.0 International License (http://creativecommons.org/licenses/by/4.0/), which permits unrestricted use, distribution, and reproduction in any medium, provided the original author and source are credited. 


\section{Materials and methods}

Ten apparently healthy goats weighing 35 to $60 \mathrm{~kg}$ within an age range of 4 to 8 years were selected from University Goat and Sheep Farm, Mannuthy and other organized farms in Thrissur district. All the goats were dewormed and the health status of each animal was evaluated by physical examination and laboratory analysis including complete blood count, examination of blood smear and faecal sample. Whole blood units were collected from the selected animals using commercially available CPDA-SAGM blood bags under aseptic conditions. Each of these units was centrifuged at $5,000 \times g$ for 7 minutes, at $4^{\circ} \mathrm{C}$ using FTBC- $6100 \mathrm{R}$ blood bank refrigerated centrifuge. After centrifugation, plasma was extracted in empty bag using plasma extractor from primary blood bag and SAGM was added from the satellite bag using the valves. After separation, pRBCs with SAGM was stored at $4 \pm 2^{\circ} \mathrm{C}$ in a dedicated refrigerator for 42 days and biochemical parameters analysed every two weeks from day 0 to day 42 . Blood $\mathrm{pH}$ was estimated with portable Oakton waterproof $\mathrm{pH}$ meter. The level of $\mathrm{GSH}$ in erythrocyte suspension was determined as per Bain et al. (2016). This method is based on the development of a yellow colour when 5,5'-dithiobis-2-nitrobenzoic acid (DTNB) is added to sulphydryl compounds. Level of lipid peroxides in erythrocyte suspension was determined by estimating MDA using the method of Okhawa et al. (1979) as modified by Al-Azzawie and Alhamdani (2006). The supernatant glucose estimation of packed RBC stored in SAGM was carried out using glucose estimation kit- GenX GLUCOSE-ML (GOD-PAP Trinders method). Potassium was estimated from the supernatant of packed red blood cells stored in CPDA/ SAGM blood bag using ion selective electrode technology.

\section{Results and discussion}

Thebiochemical parametersassessed in this study were $\mathrm{pH}$, glucose, potassium, MDA and GSH. Statistical analysis using repeated measures ANOVA was carried out to find out the changes in the variables at different period of time. In the cases where F-value was found significant, pair wise comparison was done by using least significant difference test. The mean values of biochemical parameters are as in table 1.

In this study, mean $\mathrm{pH}$ value decreased from day 0 to 42 during storage, though it was not significant. The mean value was in the range $7.18 \pm 0.03$ to $7.13 \pm 0.03$. Hess and Greenwalt (2002), opined that $\mathrm{pH}$ value above 7.2 will favor 2, 3-bisphoshoglycerate production and might affect the ATP synthesis. The permissible lower $\mathrm{pH}$ limit for the stored blood was 6.65. Reduction in $\mathrm{pH}$ values occur as RBCs remain metabolically active, with glucose breakdown and anaerobic metabolism leading to production of lactate and hydrogen ions (Mudge et al., 2004; Hess et al., 2009). However, as the decline of $\mathrm{pH}$ was not found to be significant and was within the limits, the stored blood could be used for transfusion.

Table 1. Variation of bio-chemical parameters during storage

\begin{tabular}{|l|c|c|c|c|c|}
\hline \multicolumn{1}{|c|}{ Variables } & Day 0 & Day 14 & Day 28 & Day 42 & $\begin{array}{c}\text { F-value } \\
(\text { P-value })\end{array}$ \\
\hline $\mathrm{pH}$ & $7.18 \pm 0.0389$ & $7.18 \pm 0.0327$ & $7.14 \pm 0.0371$ & $7.13 \pm 0.0367$ & $\begin{array}{l}1.317^{\mathrm{ns}} \\
(0.289)\end{array}$ \\
\hline $\begin{array}{l}\text { Glucose } \\
(\mathrm{mg} / \mathrm{dL})\end{array}$ & $650.4 \pm 18.45^{\mathrm{a}}$ & $607.5 \pm 18.92^{\mathrm{b}}$ & $573.2 \pm 22.09^{\mathrm{c}}$ & $535.5 \pm 16.92^{\mathrm{d}}$ & $\begin{array}{l}20.707^{\star *} \\
(<0.001)\end{array}$ \\
\hline $\begin{array}{l}\text { Potassium } \\
(\mathrm{mmol} / \mathrm{L})\end{array}$ & $4.02 \pm 0.22^{\mathrm{d}}$ & $6.96 \pm 0.27^{\mathrm{c}}$ & $9.61 \pm 0.39^{\mathrm{b}}$ & $13.15 \pm 0.57^{\mathrm{a}}$ & $\begin{array}{l}160.61^{\star *} \\
(<0.001)\end{array}$ \\
\hline $\begin{array}{l}\mathrm{MDA} \\
(\mu \mathrm{mol} / \mathrm{L})\end{array}$ & $10.47 \pm 1.13^{\mathrm{d}}$ & $15.15 \pm 1.36^{\mathrm{c}}$ & $20.59 \pm 1.60^{\mathrm{b}}$ & $28.16 \pm 1.76^{\mathrm{a}}$ & $\begin{array}{l}33.342^{\star *} \\
(<0.001)\end{array}$ \\
\hline $\begin{array}{l}\mathrm{GSH} \\
(\mu \mathrm{mol} / \mathrm{g} \text { of } \mathrm{Hb})\end{array}$ & $0.02 \pm 0.01^{\mathrm{d}}$ & $0.05 \pm 0.01^{\mathrm{c}}$ & $0.08 \pm 0.02^{\mathrm{b}}$ & $0.10 \pm 0.02^{\mathrm{a}}$ & $\begin{array}{l}46.62^{\star *} \\
(<0.001)\end{array}$ \\
\hline
\end{tabular}

** Significant at 0.01 level $(P<0.01)$; ns - Non-significant $(P>0.05)$

Means having different superscripts differ significantly within a row 
The mean value of glucose in supernatant reduced as the storage period increased. This is in agreement with Tavares (2013), who observed decrease in glucose values during storage from day 0 to 42 . This reduction might be due to the consumption of glucose by the metabolically active erythrocytes as an energy source. However, it has been recorded that glucose consumption of caprine erythrocytes is low in comparison to other species. Higher ATP reserves of caprine erythrocytes may also result in non-decline of glucose levels (Kaneko et al., 2008). Even at the end of storage period, significant reduction in glucose was noticed in the mean value from $573.2 \pm 22.09 \mathrm{mg} / \mathrm{dL}$ on $28^{\text {th }}$ day to $535.5 \pm$ $16.92 \mathrm{mg} / \mathrm{dL}$ on $42^{\text {nd }}$ day. This suggests that $\mathrm{RBC}$ remained metabolically active and fit for transfusion. The excess glucose in the nutrient media at the end of storage period was easily balanced post transfusion by the liver (Fonesca et al., 2018).

A significant increase was recorded in the supernatant potassium level during the study. On the $42^{\text {nd }}$ day of storage, the supernatant mean potassium value was 13.15 $\pm 0.57 \mathrm{mmol} / \mathrm{L}$, vis-à-vis day 0 value of $4.02 \pm$ $0.22 \mathrm{mmol} / \mathrm{L}$. During blood storage, a slow and continuous leakage of intracellular potassium to the plasma has been recorded. This has been considered to be associated with failure of $\mathrm{Na}^{+}-\mathrm{K}^{+}$ATPase pump (Opoku-Okrah et al., 2015). Species wise difference in intracellular potassium level has been reported (Sousa et al., 2013). Opoku-Okrah et al. (2015), stated that plasma potassium level of blood stored in CPD solution can increase by $0.5-1.0 \mathrm{mmol} / \mathrm{L}$ per day. Extracellular potassium value can be used as a marker for assessing the quality of stored erythrocytes as the ATP depletion and improper refrigeration may result in elevation of potassium in ECF as suggested by Fonesca et al. (2018). Perusal of literature did not reveal any similar study for caprine pRBC storage with regard to potassium levels. The increase in potassium in stored blood of goat was slow and constant when compared with the increased potassium levels of stored canine and human blood. Further, the values of the present study can be used as reference values for caprine pRBC storage studies.
The mean MDA values increased significantly throughout the storage from 10.47 $\pm 1.13 \mu \mathrm{mol} / \mathrm{L}$ (day 0 ) to $28.16 \pm 1.76 \mu \mathrm{mol} / \mathrm{L}$ (day 42). As MDA is an end product of lipid peroxidation, quantifying the MDA in stored blood was a useful marker to determine the extent of lipid peroxidation (Simsek et al., 2006; Nazifi et al., 2009; Pandey and Rizvi, 2011). Malondialdehyde formation indicated the loss of phospholipid from RBC membrane. Proportionating the MDA values, oxidative damage and resultant haemolysis can be assessed and viability of the cells in the storage media can be predicted (Fonesca et al., 2018). Increase in MDA values on storage of $\mathrm{pRBCs}$ in SAGM of human blood has been reported (Chaudhary and Katharia, 2012). However in a similar study of human pRBCs, increase was found to be insignificant (Mustafa et al., 2016). Similar studies with regard to stored caprine pRBCs are lacking. It has been suggested by Antosik et al. (2018) that addition of membrane interacting antioxidants like vitamin $\mathrm{E}$ analogue has beneficial effects in reducing lipid peroxidation level of RBCs stored in SAGM.

A significant increase in GSH was recorded with storage. Huyut et al. (2016) reported that MDA value and GSH value were negatively correlated. Reduced glutathione studies with respect to caprine pRBC stored in SAGM are lacking. Increase in GSH during the study period suggests antioxidant activity to manage the oxidative stress. According to Roback et al. (2011), the oxidised form of GSH is GSSG, which is not an antioxidant but it can be converted back to GSH by using NADPH derived from pentose phosphate pathway. It was also reported that supplementation of amino acid precursors can also stimulate GSH synthesis. Two other antioxidants reported were $a$ - tocoferol and ergothioneine, which are obtained from the diet or some unknown mechanisms and not synthesized by the erythrocytes. These were relatively stable during the storage. Additive used in the study, SAGM contains mannitol which acts as an antioxidant by scavenging hydroxyl radical in various systems (Antosik et al., 2018). Therefore, several factors influence the GSH values and no specific conclusion could be drawn with regard to the increase $\mathrm{GSH}$ values recorded in the present study. 


\section{Conclusion}

The suitability of CPDA/SAGM as a storage media for caprine pRBCs in the present study was assessed using biochemical parameters. Based on biochemical studies, the storage media could be considered suitable for storing caprine $\mathrm{pRBC}$ for 42 days.

\section{Acknowledgement}

The authors are thankful to the Kerala Veterinary and Animal Sciences University for providing the facilities needed for carrying out the research.

\section{Conflicts of interest}

There were no conflicts of interest reported by the authors.

\section{References}

Al-Azzawie, H.F. and Alhamdani, M.S.S. 2006. Hypoglycemic and antioxidant effect of oleuropein in alloxan-diabetic rabbits. Life Sci.78: 1371-1377.

Antosik, A., Czubak, K., Cichon, N., Nowak, P. and Zbikowska, H. 2018. Vitamin $\mathrm{E}$ analogue protects red blood cells against storage-induced oxidative damage. Transfus. Med. Hemother. 45: 347-354.

Bain, B.J., Bates, I. and Laffan, M.A.2016.Dacie and Lewis Practical Haematology. Elsevier Health Sciences, London, $600 p$.

Chaudhary, R. and Katharia, R. 2012. Oxidative injury as contributory factor for red cells storage lesion during twenty eight days of storage. Blood Transfus. 10: 59-62.

Fonseca, N., Gameleira, J.S., Cavalcante, J.M., Oliveira, F.L., Mori, C.S., Sousa, R.S., Minervino, A.H. and A BarrêtoJúnior, R. 2018. Biochemical responses, blood gas, oxidative stress and lipid peroxidation of goats transfused with fresh or stored whole homologous blood. Braz. J. Vet. Res. 38: 2070-2079.
Hess, J.R. and Greenwalt, T.G. 2002. Storage of redbloodcells:newapproaches. Transfus Med. Rev. 16: 283-295.

Hess, J.R., Sparrow, R.L., Van Der Meer, P.F., Acker, J.P., Cardigan, R.A. and Devine, D.V. 2009. Blood components: red blood cell hemolysis during blood bank storage: using national quality management data to answer basic scientific questions. Transfusion. 49: 2599-2603.

Huyut, Z., Sekeroglu, M.R., Balahoroglu, R., Karakoyun, T. and Cokluk, E. 2016. The relationship of oxidation sensitivity of red blood cells and carbonic anhydrase activity in stored human blood: effect of certain phenolic compounds. BioMed Res. Int. 2016: 1-8.

Kaneko, J.J., Harvey, J.W. and Bruss, M.L. 2008. Clinical Biochemistry of Domestic Animals. (6 $6^{\text {th }}$ Ed.). Academic press, Cambridge, 928p.

Mudge, M.C., Macdonald, M.H., Owens, S.D. and Tablin, F. 2004. Comparison of 4 blood storage methods in a protocol for equine pre-operative autologous donation. Vet. Surg. 33: 475-486.

Mustafa, I., Al Marwani, A., Mamdouh Nasr, K., Abdulla Kano, N. and Hadwan, T. 2016. Time dependent assessment of morphological changes: leukodepleted packed red blood cells stored in SAGM. BioMed. Res. Int. 2016: 1-6.

Nazifi, S., Saeb, M., Ghafari, N., Razeghian, I., Razavi, S.M., Vosoughi, F., Dehghani, F. and Orangi, H. 2009. Reference values of oxidative stress parameters in adult native Iranian goats. Bulg. J. Vet. Med. 12: 119-124.

Okhawa, H., Ohishi, N. and Yagi, K. 1979. Reaction of linoleic acid hydroperoxides with thiobarbituric acids. Analyt. Biochem. 95: 351-354.

Opoku-Okrah, C., Acquah, B.K.S. and Dogbe, E.E. 2015. Changes in potassium and sodium concentrations in 
stored blood. Pan Afr. Med. J. 20(1) DOI: 10.11604/pamj.2015.20.236.5851

Pandey, K.B. and Rizvi, S.I. 2011. Biomarkers of oxidative stress in red blood cells. Biomed. Pap. Med. Fac. Univ. Palacky Olomouc Czech. Repub. 155: 131-136.

Roback, J.D., Neuman, R.B., Quyyumi, A. and Sutliff, R. 2011. Insufficient nitric oxide bioavailability: a hypothesis to explain adverse effects of red blood cell transfusion. Transfusion. 51: 859-866.

Simsek, S., Yuce, A. and Utuk, A.E. 2006. Determinationofserummalondialdehyde levels in sheep naturally infected with
Dicrocoelium dendriticum. Firat Univ. Vet. J. HIth. Sci. 20: 217-220.

Sousa, R.S., Barrêto-Júnior, R.A., Sousa, I.K., Chaves, D.F., Soares, H.S., Barros, I.O., Minervino, A.H. and Ortolani, E.L. 2013. Evaluation of hematologic, blood gas, and select biochemical variables in ovine whole blood stored in CPDA-1 bags. Vet. Clin. Path. 42: 27-30.

Tavares, M.D.2013.Hematological, biochemical and hemogasometric evaluation of goat blood stored in CPDA-1 and CPD/ SAG-M bags. M.V.Sc thesis, Federal Rural University of the Semi-Arid, Mossoro, 76p. 